\title{
Field Evaluation of Strawberry Genotypes for Tolerance to Black Root Rot on Fumigated and Nonfumigated Soil
}

\author{
Chrislyn A. Particka ${ }^{1}$ and James F. Hancock ${ }^{2}$ \\ Department of Horticulture, Michigan State University, East Lansing, MI 48824
}

\begin{abstract}
AdDitional INDEX words. Fragaria xananassa, Rhizoctonia fragariae, Pythium spp., Pratylenchus penetrans, methyl bromide, chloropicrin, genotype $\times$ environment interaction, breeding

ABSTRACT. Black root rot (BRR) is a widespread disease of strawberry (Fragaria $\times$ ananassa Duchnesne) that causes the death of feeder roots and the degradation of structural roots. The major causal organisms of BRR include Rhizoctonia fragariae Husain and W.E. McKeen, Pythium Pringsh., and Pratylenchus penetrans (Cobb) Filipjev and Schuurmans Stekhoven. The current method of control for black root rot is methyl-bromide fumigation; however, methyl bromide is scheduled to be phased out in 2005, and its effects are short-lived in matted-row systems. The objectives of the study were to measure levels of tolerance to BRR in 20 strawberry genotypes and to determine which pathogens were present in the soil. The genotypes were planted in four blocks each of methyl-bromide fumigated and nonfumigated soil, and were evaluated for crown number, number of flowers per crown, yield, and average berry weight over 2 years. The results showed that all three pathogens were present in the field, and that there was a significant genotype $\times$ fumigation interaction for yield and crown number in both years. The cultivars Bounty, Cabot, and Cavendish, all released from the breeding program in Nova Scotia, displayed tolerance to the pathogens that cause BRR.
\end{abstract}

Black root rot is a widespread disease of strawberry that causes an overall decrease in productivity due to the death of feeder roots and the degradation of structural roots (Maas, 1998). One of the earliest reports of BRR was by Coons (1924), who noted that the roots of infected plants blackened and the cortex peeled off. By the 1950s, BRR had been reported in the United States, Canada, Europe, and Australia (Raski, 1956). Many strawberry researchers now believe that BRR has replaced red stele (Phytophthora fragariae Hickman) as the most serious root disease of strawberry in the northeastern United States (Pritts and Wilcox, 1990).

Many biotic factors have been associated with BRR. Rhizoctonia fragariae was first described as a causative organism of BRR in 1963, and since then, it has been associated with BRR in many areas of the United States and other countries (Abad et al., 1999; D’Ercole et al., 1989; Husain and McKeen, 1963). Maas (1998) concluded that $R$. fragariae is the most widespread pathogen that causes BRR, although many Pythium species have also been associated with the disease (Nemec and Sanders, 1970). Pythium ultimum Trow is considered to be the most common one (Wilhelm, 1998). The root lesion nematode (Pratylenchus penetrans) was first associated with strawberry in 1931, and it was linked to BRR by many researchers in the mid-1950s to early 1960s (Klinkenberg, 1955; Steiner, 1931; Townshend, 1962).

While $R$. fragariae, Pythium, and $P$. penetrans have been separately implicated as the cause of BRR, the disease is often caused by a complex of all three. Chen and Rich (1962) found that fungi infected areas of the root damaged by P. penetrans more readily than healthy tissue, and that the nematodes moved away from the roots as fungi invaded. LaMondia and Martin (1989) determined that infection by $P$. penetrans consistently raised the severity of BRR caused by $R$. fragariae.

Several abiotic factors have been associated with BRR. Fletcher (1917) attributed BRR to winter injury, poor culture, lack of

Received for publication 17 Dec. 2004. Accepted for publication 19 Mar. 2005. ${ }^{1}$ Graduate Assistant.

${ }^{2}$ Professor. fertility, plant crowding, insufficient mulch, and wet soils. Wing et al. (1995a) found that soil compaction, fine-textured soils, age of the planting, successive years of strawberry monoculture, use of the herbicide terbacil, and non-use of raised beds and of the fungicide metalaxyl all increased incidence of BRR.

Currently, there are no effective, long-lasting control measures for BRR in perennial matted row culture. Fumigation with methyl bromide and chloropicrin has been reported to give good control in annual systems (Maas, 1998); however, its effects gradually wear off in perennial matted row systems as pathogen populations reestablish over time. Some have even suggested that fumigation could ultimately result in an increase in BRR in perennial systems, as fumigation kills beneficial soil microbes, leaving nothing to compete with the pathogens that either survive in low numbers or are reintroduced to the field (Pritts and Wilcox, 1990). Methyl bromide is scheduled to be phased out in 2005 (USDA, 2000), and while cost-effective chemical alternatives to methyl bromide have been identified, none provide the full spectrum of control that methyl bromide does (Fennimore et al., 2003; Shaw and Larson, 1999).

Many researchers have looked to crop rotation and cover crops to help mitigate the effects of BRR. Morgan and Collins (1964) studied the effect of different cover crops and organic soil amendments on $P$. penetrans populations and found that composted timothy hay (Phleum pratense L.) was most effective in reducing nematode numbers. LaMondia et al. (2002) found that rotation to 'Saia' oats (Avena strigosa Schreb.) and Triple S sorghum-sudangrass [Sorghum bicolor Durra x S. sudanense (Piper) Stapf.] suppressed both $R$. fragariae and $P$. penetrans, while 'Garry' oats (Avena sativa L.) suppressed $R$. fragariae but increased P. penetrans. Recent studies conducted at Cornell Univ. found that fumigation with methyl bromide resulted in the highest yield, but a rotation of kale (Brassica oleracea L. var. acephala DC.)/sweet corn [Zea mays L. var. saccharata (Sturt.) Bailey]/rye (Secale cereale L.) also proved to be effective (Seigies, 2004). Overall, rotations involving multiple species fared much better than rotations involving single species. 
The most effective way to control BRR would be to identify or to develop tolerant strawberry cultivars. A few studies have been undertaken to identify genotypes with tolerance to the pathogens causing BRR, but most new eastern cultivar releases have not been screened.

Potter and Dale (1994) conducted studies to determine if tolerance to $P$. penetrans alone could be found in strawberry, and showed that 'Guardian' had the highest resistance overall. Further studies showed considerable variation among 19 cultivars, with the four most resistant being 'Pajaro', 'Chandler', Annapolis', and 'Glooscap' (Dale and Potter, 1998). Interestingly, all these have the California cultivar Lassen in their pedigree.

Wing et al. (1995b) found that 'Tristar', 'Earliglow', and 'Midway' had the healthiest roots in a field infected primarily with Pythium spp. However, disease incidence in this field was relatively low as no above ground symptoms were observed, and Rhizoctonia spp. and the root lesion nematode were absent. Studies in California on fumigated and nonfumigated soils that measured leaf number, plant diameter, yield, fruit weight, and fruit appearance did not identify any genotypes with strong tolerance to sublethal levels of soil pathogens (Larson and Shaw, 1995; Shaw and Larson, 1996). In the first study, the interaction between genotype and fumigation was not significant, but this interaction was significant in the second study. The authors pointed out, however, that the interaction explained only $2 \%$ to $5 \%$ of the variance, and concluded that the lack of fumigation affected all cultivars similarly. In the first study, only California genotypes were tested, and in the second study, nine genotypes from outside California (six of which were from the USDA program in Maryland) and nine California genotypes were used, which represented only a small fraction of the germplasm grown.

Studies in Michigan identified only modest differences in tolerance based on yield, fruit weight, crown and runner number, and root and crown appearance in fields infested with Pythium spp., Rhizoctonia spp., Idriella lunata P.E. Nelson \& K. Wilh., Meloidognye hapla Chitwood, and P. penetrans (Hancock et al., 2001). This study included four California cultivars, 11 eastern U.S. cultivars, and $12 \mathrm{~F}$. virginiana Duchnesne $\mathrm{F}_{1}$ hybrids. Although no significant genotype $\times$ fumigation interactions were found, there was a significant source $\times$ fumigation interaction for fruit weight at $P \leq 0.01$, and for yield and runner number at $P$ $\leq 0.10$. Also, the $F$. virginiana hybrids performed better overall than the eastern or California cultivars, and the authors concluded that some tolerance might exist in $F$. virginiana, which could be used to improve current cultivars.

Herein we describe a field screen for BRR tolerance that included both old and new cultivars from six breeding programs, as well as one wild genotype. We focused on yield and vigor of the aboveground portion of the plants evaluated with and without fumigation, and found a number of cultivars developed in Nova Scotia that had considerable tolerance.

\section{Materials and Methods}

We evaluated 19 cultivars and one F. virginiana genotype (Table 1). The planting was established in June 2002 at the Horticulture Teaching and Research Center in Holt, Mich., on soil that had been in strawberries for over 5 years. Plants were obtained from commercial nurseries, and were planted in a split-plot design with four plots each of nonfumigated soil and soil that had been treated with a mixture of 2 methyl bromide : 1 chloropicrin $(\mathrm{w} / \mathrm{w})$ injected at a rate of $392 \mathrm{kgha}^{-1}$. Three plants of each genotype were planted in each plot, with $46 \mathrm{~cm}$ within-row spacing and $61 \mathrm{~cm}$ between-row spacing. The plots received supplemental irrigation as needed, and weeds were controlled through use of preemergence herbicides and mechanical methods. At the end of the first fruiting season, we selected 10 genotypes that appeared to represent the range of variation for tolerance to BRR (Table 1 ), and the rest of the genotypes were removed to simplify plot maintenance.

The plants were allowed to runner freely, with sufficient training to keep plants of different genotypes separated. In the fall of year 1 (2002-03 season) and year 2 (2003-04 season), the total number of crowns was recorded in each plot ( 8 Nov. and 24 Oct., respectively). Individual plants were not counted, but most were represented by one or two crowns. In the spring of year 1 and year 2, the number of flowers per crown was counted (27 May and 21 May, respectively). During the fruiting season each year (11 June-9 July 2003 and 3 June-29 June 2004), fruit that were at least $60 \%$ ripe were harvested and weighed weekly. A 25-berry sample was taken from each genotype in each plot to determine average fruit weight. Crown and yield data were divided by the number of surviving mother plants for analysis, as in a few instances, not all of the original plants survived.

In both years, root samples were taken from randomly selected plants to determine presence of plant parasitic nematodes (14-21 July 2003 and 12-17 May 2004) and fungal pathogens (14 July 2003 and 28 Sept. 2004). For nematode isolation, two plants were randomly selected from the 10 genotypes included in both years of the study from each of the plots (for a total of 160 plants). Plants were dug using a hand spade and were placed in plastic bags on ice and then stored at $1.5^{\circ} \mathrm{C}$ until they were processed the following day. Nematodes were extracted from root tissue following the flask-shaker method (Bird, 1971). To make up a 1 -g sample, $\approx 0.5 \mathrm{~g}$ of roots were selected from the two plants from each plot, for a total of 80 composite samples. For fungal isolation, $\approx 100$ plants were randomly selected from the same 10 genotypes in both fumigated and nonfumigated plots, but samples were not kept separate for genotype or treatment. Plants were dug using a hand spade and were placed in plastic bags on ice and stored at $1.5^{\circ} \mathrm{C}$ until they were processed later in the day or the following day. Fungi were isolated from roots by washing the root systems in running water, and selecting root segments that had visible lesions. The root segments were cut into 1-cm-long sections, surface-sterilized in $1 \% \mathrm{NaOCl}$ for $3 \mathrm{~min}$, rinsed three times in sterile distilled water, and were blotted dry on sterile filter paper. At least 80 segments were used both times fungi were isolated. The root pieces were placed on selective medium [1/4 strength acidified PDA supplemented with ampicillin (50 $\left.\mu \mathrm{g} \cdot \mathrm{mL}^{-1}\right)$ and streptomycin $\left.\left(20 \mu \mathrm{g} \cdot \mathrm{mL}^{-1}\right)\right]$ and were transferred to fresh media as needed for identification. Fungi were identified based on the morphology of hyphae and of spores (Barnett and Hunter, 1998; Maas, 1998).

Model variance components due to fumigation, genotype, and fumigation $\times$ genotype treatment interaction and error were estimated as in Larson and Shaw (1995). The analysis of variance was conducted using the GLM function of SAS (SAS Institute, Cary, N.C.), with years being analyzed separately, as half the genotypes were removed after the first year.

\section{Results and Discussion}

Pathogens Present. Over 90\% of the nematodes isolated were the root lesion nematode, Pratylenchus Filipjev. Fumiga- 
Table 1. Strawberry genotypes grown on fumigated and nonfumigated soil in Holt, Mich.

\begin{tabular}{|c|c|c|c|}
\hline Genotype & Year released & Parentage & Origin \\
\hline Allstar & 1981 & US $4419 \times$ MDUS 3184 & USDA-Beltsville, Md. \\
\hline Annapolis & 1984 & K74-5 x Earliglow & AAFC $^{\mathrm{z}}$, Kentville, N.S. \\
\hline Bounty $^{\mathrm{y}}$ & 1972 & Jerseybelle $\mathrm{x}$ Senga Sengana & AAFC, Kentville, N.S. \\
\hline Brunswick & 1999 & Cavendish $\mathrm{x}$ Honeoye & AAFC, Kentville, N.S. \\
\hline Cabot $^{y}$ & 1998 & K78-5 x K86-19 & AAFC, Kentville, N.S. \\
\hline Cavendish $^{\mathrm{y}}$ & 1990 & Glooscap x Annapolis & AAFC, Kentville, N.S. \\
\hline Chandler & 1983 & Douglas x Cal 72.361-105 & Univ. of California, Davis \\
\hline Earliglow & 1975 & MDUS $2359 \times$ MDUS 2713 & USDA-Beltsville, Md. \\
\hline Evangeline & 1999 & Honeoye x Veestar & AAFC, Kentville, N.S. \\
\hline Governor Simcoe & 1985 & Holiday $x$ Guardian & HRIO $^{x}$, Simcoe, Ont. \\
\hline Guardian $^{\mathrm{y}}$ & 1969 & NC $1768 \times$ Surecrop & USDA-Beltsville, Md. \\
\hline Honeoye & 1979 & Vibrant $x$ Holiday & NYSAES ${ }^{\mathrm{w}}$, Geneva, N.Y. \\
\hline Jewel $^{\mathrm{y}}$ & 1985 & NY 1221 x Holiday & NYSAES, Geneva, N.Y. \\
\hline Kent $^{\mathrm{y}}$ & 1981 & K $68-5$ x Raritan & AAFC, Kentville, N.S. \\
\hline LH50-4 $4^{y}$ & --- & --- & Native $F$. virginiana from Montana \\
\hline Mesabi & 2000 & Glooscap x MNUS 99 & University of Minnesota, St. Paul \\
\hline Midway $^{\mathrm{y}}$ & 1960 & Dixieland $\mathrm{x}$ Temple & USDA-Beltsville, Md. \\
\hline Mira & 1995 & Scott $x$ Raritan & AAFC, Kentville, N.S. \\
\hline Surecrop & 1956 & Fairland x MDUS 1972 & USDA-Beltsville, Md. \\
\hline Winona $^{\mathrm{y}}$ & 1995 & Earliglow x MNUS 52 & $\begin{array}{l}\text { Univ. of Minnesota, St. Paul and } \\
\text { USDA-Beltsville, Md. }\end{array}$ \\
\hline
\end{tabular}

tion with methyl bromide was effective at killing the root lesion nematode, and they did not move back into fumigated areas during the study. In samples from fumigated soil, $5 \%$ contained the root lesion nematode in year 1 , and only $8 \%$ did in year 2 ; numbers ranged from two to 54 per gram of root tissue across years, with an average of two. One hundred percent of the samples from nonfumigated soil contained the root lesion nematode in year 1 , while $85 \%$ of the samples contained them in year 2 . Root lesion nematode numbers ranged from two to 152 nematodes per gram of root from nonfumigated soil, with an average of 28 . No significant differences in nematode number were observed across genotypes in either year $(P=0.200, \mathrm{df}=9$ in year $1 ; P=$ 0.249 , df $=9$ in year 2).

Rhizoctonia spp. and Pythium spp. were the most common pathogenic fungi present in the soil. In year 1 Pythium spp. were found in many more samples than Rhizoctonia spp., but unfor- tunately, the relative percentages were not recorded. In year 2, Rhizoctonia spp. was isolated from $43 \%$ of the root segments, while Pythium spp. was isolated from only one sample. Cylindrocarpon destructans (Zinnsmeister) Scholten, which has also been associated with BRR (Wilhelm, 1998), was also isolated from three root segments in year 2. Differences in the most common type of pathogen found between year 1 (samples were collected on 14 July) and year 2 (samples were collected on 28 Sept.) is most likely due to the difference in sampling date. Rhizoctonia fragariae is not parasitic on strawberry roots under warm temperatures, and is therefore replaced by other pathogens during the spring and summer (Husain and McKeen, 1963).

Overall CUlTivar PERFormance. In year 1, mean yields across treatments were highest for 'Mesabi', 'Cabot', 'Bounty', 'Brunswick', 'Annapolis', and 'Cavendish', all of which produced at least $900 \mathrm{~g}$ (Table 2). Each of these genotypes produced their 
Table 2. Analysis of variance and variance components for yield, crown number, number of flowers per crown, and fruit weight of strawberry genotypes grown in Holt, Mich., on fumigated and nonfumigated soil. Plants were set in 2001 and evaluated over 2 years.

\begin{tabular}{|c|c|c|c|c|c|c|c|c|}
\hline \multirow[b]{2}{*}{ Source } & \multicolumn{2}{|c|}{ Yield $(\mathrm{g} / \text { plant })^{\mathrm{z}}$} & \multicolumn{2}{|c|}{ Crowns (no./plant) ${ }^{\mathrm{z}}$} & \multicolumn{2}{|c|}{ Flowers (no./crown) } & \multicolumn{2}{|c|}{ Avg fruit wt $(\mathrm{g})$} \\
\hline & Year 1 & Year 2 & Year 1 & Year 2 & Year 1 & Year 2 & Year 1 & Year 2 \\
\hline \multicolumn{9}{|l|}{ Fumigation } \\
\hline Fumigated & 902.9 & 825.5 & 15.8 & 39.3 & 8.7 & 14.5 & 10.7 & 8.2 \\
\hline Non-fumigated & 484.8 & 556.7 & 8.4 & 23.2 & 9.7 & 13.0 & 10.3 & 7.4 \\
\hline \multicolumn{9}{|l|}{ Genotype } \\
\hline Allstar & 595.4 & --- & 8.8 & --- & 8.8 & --- & 11.4 & --- \\
\hline Annapolis & 995.8 & --- & 13.6 & --- & 8.5 & --- & 12.9 & --- \\
\hline Bounty & 1062.7 & 875.8 & 18.1 & 35.0 & 9.3 & 18.5 & 8.4 & 6.0 \\
\hline Brunswick & 1051.5 & --- & 15.5 & --- & 8.5 & --- & 11.2 & --- \\
\hline Cabot & 1081.1 & 973.0 & 12.3 & 29.3 & 8.3 & 12.1 & 16.6 & 12.7 \\
\hline Cavendish & 900.0 & 886.3 & 10.9 & 20.4 & 9.1 & 15.6 & 12.9 & 10.2 \\
\hline Chandler & 280.5 & --- & 8.7 & --- & 5.1 & --- & 10.3 & -- \\
\hline Earliglow & 737.0 & -- & 10.4 & -- & 9.4 & -- & 10.1 & -- \\
\hline Evangeline & 696.2 & --- & 14.8 & --- & 6.8 & --- & 10.3 & -- \\
\hline Gov. Simoce & 605.2 & --- & 11.6 & --- & 7.9 & -- & 8.9 & -- \\
\hline Guardian & 378.6 & 491.8 & 15.1 & 30.2 & 6.5 & 14.5 & 7.3 & 6.9 \\
\hline Honeoye & 681.4 & --- & 10.2 & --- & 8.0 & --- & 10.4 & --- \\
\hline Jewel & 796.2 & 966.4 & 11.1 & 24.6 & 8.9 & 15.5 & 13.8 & 9.4 \\
\hline Kent & 719.2 & 591.0 & 7.5 & 13.8 & 10.5 & 19.2 & 11.7 & 8.0 \\
\hline LH50-4 & 61.7 & 76.4 & 19.5 & 91.0 & 28.4 & 9.9 & 1.4 & 1.0 \\
\hline Mesabi & 1104.5 & 952.1 & 13.2 & 24.5 & 10.4 & 13.9 & 11.7 & 7.5 \\
\hline Midway & 269.2 & 264.7 & 7.3 & 15.7 & 6.8 & 8.4 & 7.9 & 5.8 \\
\hline Mira & 798.3 & --- & 12.6 & --- & 8.2 & -- & 12.1 & --- \\
\hline Surecrop & 564.3 & --- & 10.7 & --- & 7.6 & -- & 8.5 & -- \\
\hline Winona & 498.7 & 833.5 & 10.0 & 27.7 & 7.9 & 10.1 & 12.0 . & 10.4 \\
\hline Mean & 693.9 & 691.1 & 12.1 & 31.3 & 9.2 & 13.8 & 10.5 & 7.8 \\
\hline
\end{tabular}

ANOVA

Significance $(P)$

\begin{tabular}{|c|c|c|c|c|c|c|c|c|}
\hline Genotype (G) & $<0.001$ & $<0.001$ & $<0.001$ & $<0.001$ & $<0.001$ & 0.027 & $<0.001$ & $<0.001$ \\
\hline Fumigation $(\mathrm{F})$ & $<0.001$ & 0.001 & $<0.001$ & $<0.001$ & 0.045 & 0.313 & 0.262 & 0.019 \\
\hline $\mathrm{G} \times \mathrm{F}$ & 0.004 & 0.023 & 0.008 & 0.005 & 0.052 & 0.501 & 0.050 & 0.365 \\
\hline & $75,446(33)^{y}$ & $109,546(41)$ & $17.8(37)$ & $153.0(19)$ & $7.5(25)$ & $50.1(69)$ & $4.6(34)$ & $2.1(17)$ \\
\hline & $34,717(15)$ & $55,086(21)$ & $0.0(0)$ & $360.4(44)$ & $20.1(67)$ & $9.5(13)$ & $8.1(59)$ & $9.9(80)$ \\
\hline & $103,633(46)$ & $68,058(26)$ & $29.5(61)$ & $209.7(26)$ & $1.4(5)$ & $0.0(0)$ & $0.8(6)$ & $0.3(3)$ \\
\hline & 227,558 & 264,132 & 48.1 & 811.4 & 30.0 & 72.2 & 13.7 & 12.4 \\
\hline
\end{tabular}

high yields in different ways. 'Mesabi' ranked in the top third of all genotypes for crown number, number of flowers/crown, and fruit weight. 'Cabot' ranked only in the upper half of all genotypes for crown number and number of flowers/crown, but had the largest fruit. 'Bounty' ranked in the bottom third for fruit weight, but was in the top third for crown number and number of flowers/crown. 'Brunswick' was intermediate for number of flowers/crown and fruit weight, but ranked in the top third for crown number. 'Annapolis' was only intermediate for number of flowers/crown, but ranked in the top third for crown number and fruit weight. 'Cavendish' was intermediate for crown number, but ranked in the top third for number of flowers/crown and fruit weight.

In year 2, 'Brunswick' and 'Annapolis' were dropped from the study, but 'Mesabi', 'Cabot', Bounty', and 'Cavendish' remained among the highest producers, joined by 'Jewel' and 'Winona'. Again, their high yields were achieved in different ways. 'Bounty' remained near the bottom for fruit weight, but was one of the highest for crown number and number of flowers/crown. 'Cabot' had the largest fruit and was in the top third for crown number, but had only intermediate number of flowers/crown. 'Cavendish' ranked high for number of flowers/crown and fruit weight, but was low for crown number. 'Mesabi' was intermediate for all three yield components. 'Jewel' and 'Winona' had intermediate crown numbers and numbers of flowers/crown, but were in the top third for fruit weight.

EFFECTS OF FUMIGATION ON YIELD COMPONENTS OF GENOTYPES. Fumigation resulted in increased yield in both years of the study; yield on fumigated soil was $46 \%$ higher $(P<0.001)$ in year 1 and $33 \%$ higher $(P<0.001)$ in year 2 (Table 2$)$. Crown number was 
also significantly higher on fumigated plots. In year 1 , fumigation resulted in $47 \%$ more crowns $(P<0.001)$, and in year 2 , crowns were increased by $41 \%(P<0.001)$. Individual fruit weight was significantly higher on nonfumigated plots in year $2(P=$ $0.019)$, but by just $10 \%$. The number of flowers per crown was not significantly different between fumigated and nonfumigated plots in either year.

The genotype $\times$ fumigation interaction for yield was significant in both years, indicating that some genotypes are more tolerant to BRR than others (Table 2). The interaction explained $46 \%$ of the variance in year 1 , and $26 \%$ in year 2 . In year 1 , the highest overall producers, 'Bounty', 'Brunswick', 'Cabot', and 'Cavendish', had high yields (866-790 g) on nonfumigated soil, and their yields were reduced by only $25 \%$ to $35 \%$ without fumigation (Fig. 1A). In contrast, 'Annapolis' and 'Mesabi' had only moderate yields on nonfumigated soil (572 and $483 \mathrm{~g}$, respectively), and their yields were reduced by $60 \%$ to $70 \%$. In year 2, 'Cabot', 'Bounty', and 'Cavendish' remained the highest producers on nonfumigated soil (over $800 \mathrm{~g}$ ) and their yields were reduced by $<20 \%$ without fumigation (Fig. 2A). Yields of 'Mesabi', 'Jewel', and 'Winona' were again $<600 \mathrm{~g}$ on nonfumigated soil and were reduced by over $50 \%$ without fumigation. This indicates that while 'Mesabi', 'Jewel', and 'Winona' are vigorous and have high yield potentials, they have little tolerance to the pathogens that cause BRR. 'Bounty', 'Brunswick', 'Cabot', and 'Cavendish' all have high yield potentials and are tolerant to BRR.

The genotype $\times$ fumigation interaction was significant for crown number in both years, mirroring the yield data (Table 2). The interaction explained $61 \%$ of the variance in year 1 , and $26 \%$ in year 2. In year 1, 'Cavendish' had among the highest crown numbers (11) on nonfumigated soil, and had only $7 \%$ fewer crowns than fumigated soil (Fig. 1B). 'Bounty', 'Brunswick', 'Cabot', and 'Annapolis' also had very high crown numbers (9-13), but their numbers were reduced by $40 \%$ to $50 \%$ without fumigation. 'Mesabi' had a rather low number of crowns on nonfumigated soil (6), and the crown numbers were reduced by $68 \%$.

The number of flowers per crown was not significant for the genotype $\times$ fumigation interaction in either year (Table 2). This suggests that the number of flowers per crown is not involved in the yield reductions seen on nonfumigated soil.

The fumigation $\times$ genotype interaction was significant for fruit weight in year 1 (Table 2); however, the interaction explained only $6 \%$ of the variance, and fumigation did not appear to have a consistent effect across genotypes. Average berry weight was higher on nonfumigated soil for seven genotypes and lower for 13 (Fig. 1C). Many authors have reported a significant decrease in berry size on nonfumigated soil that was strongly associated with yield reductions (Hancock et al., 2001; Larson and Shaw, 1995; Shaw and Larson, 1996). Our results indicate that while berry weight can be reduced on nonfumigated soil, the effect is modest (10\% or less) and variable across genotypes, making reductions in crown number much more important in effecting yields on nonfumigated fields of matted row cultivars.

Potential fOR BREeding NeW CUltivars Resistant to BRR. Based on our studies, we feel there is sufficient variability to breed for increased tolerance to BRR. Especially impressive are the cultivars from the breeding program of Agriculture and Agri-Food Canada in Nova Scotia - all eight of those included in the study were in the top half for yield on nonfumigated soil in year 1 (Fig. 1A), and in the second year of the study, the four that were included were ranked first, second, third, and fifth (Fig. 2A). These cultivars also were the most tolerant to BRR, being
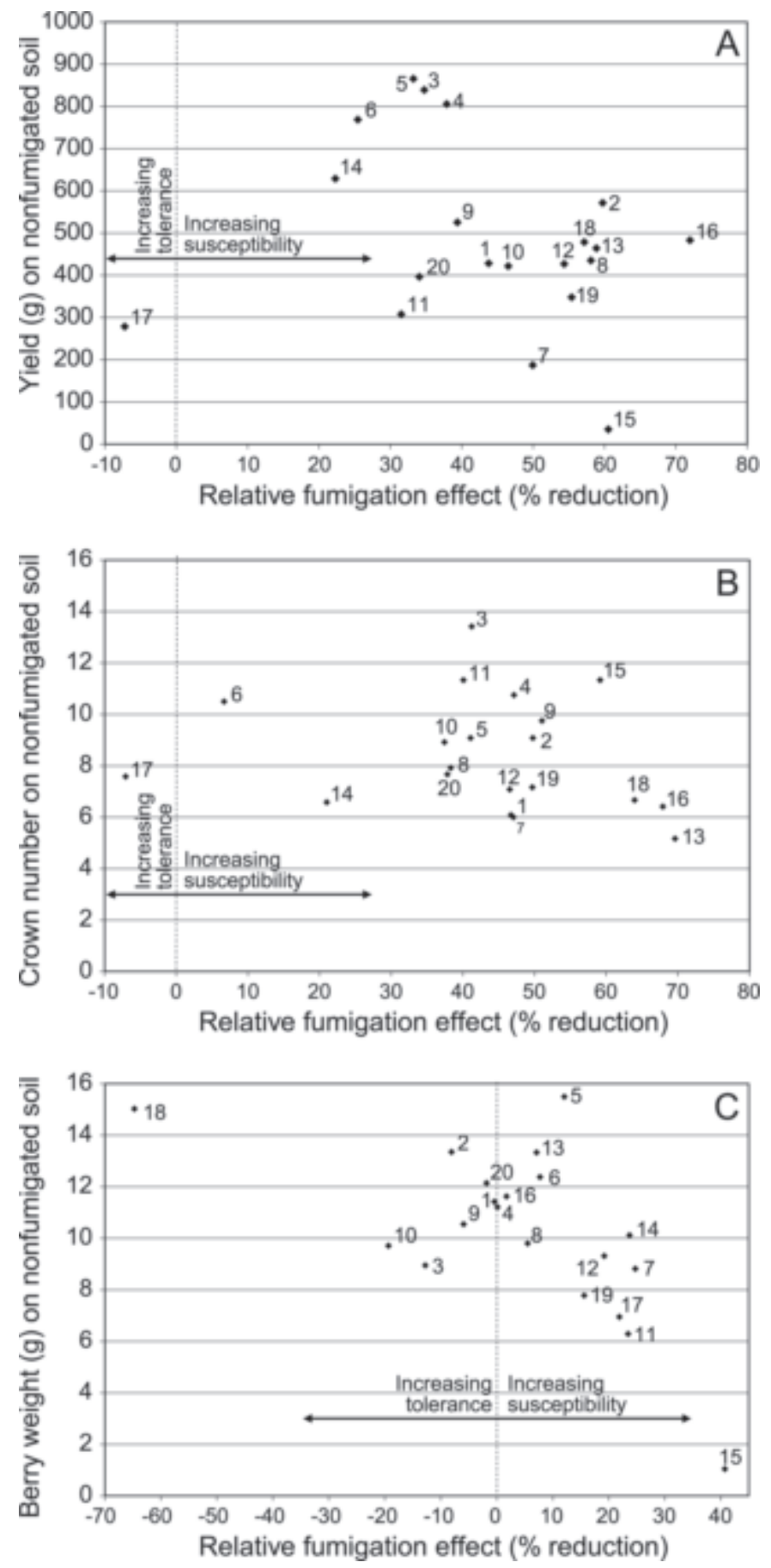

Fig. 1. Plots showing (A) yield, (B) crown number, and (C) average berry weight and relative fumigation effect (percent reduction on nonfumigated soil compared to fumigated soil) in year 1 for 20 strawberry genotypes grown at Holt, Mich. Yield and crown number are expressed as the amount/surviving mother plant in a plot. Positive values for percent reduction indicate the value was lower on nonfumigated soil, while negative values indicate the value was higher on nonfumigated soil. The genotypes were (1) 'Allstar', (2) 'Annapolis', (3) 'Bounty', (4) 'Brunswick', (5) 'Cabot', (6) 'Cavendish', (7) 'Chandler', (8) 'Earliglow', (9) 'Evangeline', (10) 'Governor Simcoe', (11) 'Guardian', (12) 'Honeoye', (13) 'Jewel', (14) 'Kent', (15) LH50-4, (16) 'Mesabi', (17) 'Midway', (18) 'Mira', (19) 'Surecrop', and (20) 'Winona'. 

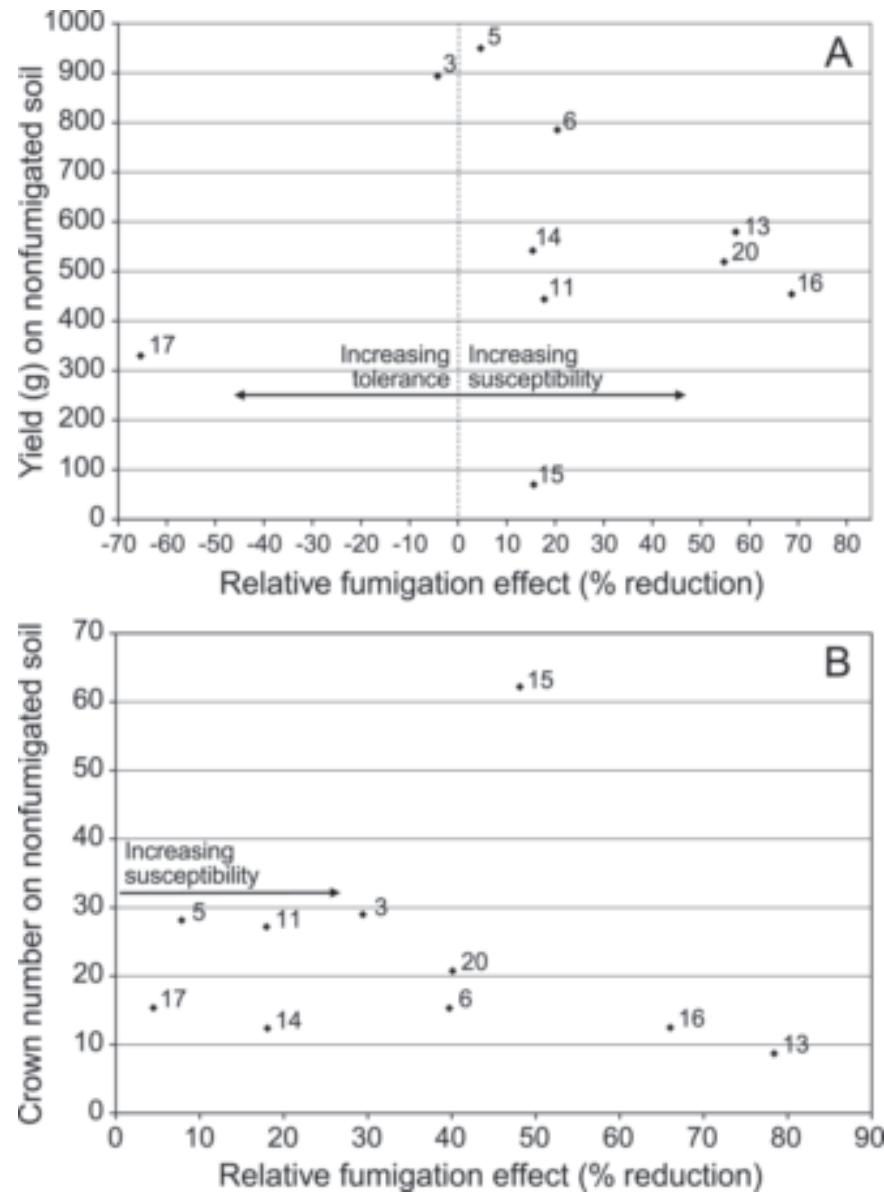

Fig. 2. Plots showing (A) yield and (B) crown number and relative fumigation effect (percent reduction on nonfumigated soil compared to fumigated soil) in year 2 for 10 strawberry genotypes grown at Holt, Mich. Yield and crown number are expressed as the amount/surviving mother plant in a plot. Positive values for percent reduction indicate the value was lower on nonfumigated soil, while negative values indicate the value was higher on nonfumigated soil. The genotypes were (3) 'Bounty', (5) 'Cabot', (6) 'Cavendish', (11) 'Guardian', (13) 'Jewel', (14) 'Kent', (15) LH50-4, (16) 'Mesabi', (17) 'Midway', and (20) 'Winona'.

among the lowest in percent reduction on nonfumigated soil. This means there is opportunity to combine vigor and tolerance to increase overall performance in soils infested with the pathogens that cause BRR.

In previous studies conducted in California and Michigan, little genetic diversity was found that could be utilized in increasing tolerance to soil pathogens (Hancock et al., 2001; Larson and Shaw, 1995; Shaw and Larson, 1996), but the top-performing cultivars from Nova Scotia ('Bounty', 'Brunswick', 'Cabot', and 'Cavendish') were not used in these studies. In examining the pedigrees of the cultivars from Nova Scotia, it was not evident that there was a single source of tolerance; no one genotype was present in these cultivars that was not also present in cultivars from other programs. However, methyl bromide has not been used in the Nova Scotia breeding plots (A. Jamieson, personal communication), as it has in most other breeding programs, suggesting that tolerant genotypes can be selected in the presence of pathogen pressure.

\section{Literature Cited}

Abad, Z.G., F.J. Louws, and G.E. Fernandez. 1999. Rhizoctonia and Pythium species associated with black root rot of strawberries in North Carolina. Phytopathology 89(6):S1 (Abstr.)
Barnett, H.L. and B.B. Hunter. 1998. Illustrated genera of imperfect fungi. 4th ed. APS Press, St. Paul, Minn.

Bird, G.W. 1971. Influence of incubation solution on the rate of recovery of Pratylenchus brachyurus from cotton roots. J. Nematol. 3:378-385.

Chen, T.A. and A.E. Rich. 1962. The role of Pratylenchus penetrans in the development of strawberry black root rot. Plant Dis. Rptr. 46(12):839-843.

Coons, G.H. 1924. Black root rot of strawberry. Mich. Agr. Expt. Sta. Quarterly Bul. 7(1):25-26.

Dale, A. and J.W. Potter. 1998. Strawberry cultivars vary in their resistance to northern lesion nematode. J. Nematol. 30:577-580.

D'Ercole, N., P. Nipoti, and D. Manzali. 1989. Research on the root rot complex of strawberry plants. Acta Hort. 265:497-506.

Fennimore, S.A., M.J. Harr, and H.A. Ajwa. 2003. Weed control in strawberry provided by shank- and drip-applied methyl bromide alternative fumigants. HortScience 38:55-61.

Fletcher, S. 1917. Strawberry growing. Macmillan, New York.

Hancock, J.F., P.W. Callow, S. Serçe, and A.C. Schilder. 2001. Relative performance of strawberry cultivars and native hybrids on fumigated and nonfumigated soil in Michigan. HortScience 36:136-138.

Husain, S.S. and W.E. McKeen. 1963. Rhizoctonia fragariae sp. nov. in relation to strawberry degeneration in southwestern Ontario. Phytopathology 53:532-540.

Klinkenberg, C.H. 1955. Nematode diseases of strawberries in the Netherlands. Plant Dis. Rptr. 39(8):603-606.

LaMondia, J.A. and S.B. Martin. 1989. The influence of Pratylenchus penetrans and temperature on black root rot of strawberry by binucleate Rhizoctonia spp. Plant Dis. 73(2):107-110.

LaMondia, J.A., W.H. Elmer, T.L. Mervosh, and R.S. Cowles. 2002. Integrated management of strawberry pests by rotation and intercropping. Crop Protection 21:837-846.

Larson, K.D. and D.V. Shaw. 1995. Relative performance of strawberry genotypes on fumigated and nonfumigated soils. J. Amer. Soc. Hort. Sci. 120:274-277.

Maas, J.L. 1998. Compendium of strawberry diseases. 2nd ed. APS Press, St. Paul, Minn.

Morgan, G.T. and W.B. Collins. 1964. The effect of organic treatments and crop rotation on soil populations of Pratylenchus penetrans in strawberry culture. Can. J. Plant Sci. 44:272-275.

Nemec, S. and H. Sanders. 1970. Pythium species associated with strawberry root necrosis in southern Illinois. Plant Dis. Rptr. 54(1):49-51.

Potter, J.W. and A. Dale. 1994. Wild and cultivated strawberries can tolerate or resist root-lesion nematode. HortScience 29:1074-1077.

Pritts, M. and W.F. Wilcox. 1990. Black root rot disease of strawberry. Cornell Small Fruits Nswl. 5(4):1-2.

Raski, D.J. 1956. Pratylenchus penetrans tested on strawberries grown on black-root-rot soil. Plant Dis. Rptr. 40(8):690-693.

Seigies, A.C. 2004. Overcoming strawberry replant disorder through diversified rotations. MS Thesis, Dept. of Horticulture, Cornell Univ., Ithaca, N.Y.

Shaw, D.V. and K.D. Larson. 1996. Relative performance of strawberry cultivars from California and other North American sources in fumigated and nonfumigated soils. J. Amer. Soc. Hort. Sci. 121:764-767.

Shaw, D.V. and K.D. Larson. 1999. Ameta-analysis of strawberry yield response to preplant soil fumigation with combinations of methyl bromidechloropicrin and four alternative systems. HortScience 34:839-845.

Steiner, G. 1931. Tylenchus pratensis de Man on tobacco, tomato, and strawberry. Plant Dis. Rptr. 15:106-107.

Townshend, J.L. 1962. The root lesion nematode Pratylenchus penetrans (Cobb 1917) Filip. \& Stek., 1941, in strawberry in the Niagra Peninsula and Norfolk County in Ontario. Can. J. Plant Sci. 42:728-736.

U.S. Department of Agriculture. 2000. Economic implications of the methyl bromide phaseout. Agr. Info. Bul. No. 756, Washington, D.C.

Wilhelm, S. 1998. Black root rot, p. 53. In: J.L. Maas (ed.). Compendium of strawberry diseases. 2nd ed. Amer. Phytopathol. Soc., St. Paul, Minn.

Wing, K.B, M.P. Pritts, and W.F. Wilcox. 1995a. Biotic, edaphic, and cultural factors associated with strawberry black root rot in New York. HortScience 30:86-90.

Wing, K.B., M.P. Pritts, and W.F. Wilcox. 1995b. Field resistance of 20 strawberry cultivars to black root rot. Fruit Var. J. 49(2):94-98. 